\title{
Values in Action (VIA) and Counseling Psychology
}

\author{
Samia Ben Youssef Mnif \\ Faculty of Humanities, Unité de rechercheEcotidi, Tunis, Tunisia \\ Email: samiabymnif@gmail.com
}

How to cite this paper: Ben Youssef Mnif, S. (2019). Values in Action (VIA) and Counseling Psychology. Psychology, 10, 903-915.

https://doi.org/10.4236/psych.2019.106058

Received: March 27, 2019

Accepted: May 26, 2019

Published: May 29, 2019

Copyright (C) 2019 by author(s) and Scientific Research Publishing Inc. This work is licensed under the Creative Commons Attribution International License (CC BY 4.0).

http://creativecommons.org/licenses/by/4.0/

\begin{abstract}
Character strengths have been the subject of various researches and positive interventions in different fields of application of psychology: in the workplace, at school, in healthcare, etc. Yet, research on the application of character strengths in the field of counseling psychology is very discrete. The current article presents the relevance of the rapprochement between positive psychology and counselling psychology through the study of character strengths. It exposes the relevance of an approach based on character strengths that allow the individual to prosper and live subjective happy experiences, especially in the field of career guidance. The article concludes by the various positive interventions based on the model of character strengths that are applied to counselling, especially during periods of professional transition.
\end{abstract}

\section{Keywords}

Values in Action, Values in Action Inventory of Strengths, Counseling Psychology

\section{Introduction}

The $21^{\text {st }}$ century is witnessing abundant and diverse publications in positive psychology (Seligman \& Csikszentmihalyi, 2000; Peterson \& Seligman, 2004; Peterson, 2006; Martin-Krumm, Tarquinio, \& Delle Fave, 2011; Niemiec, 2013; McGrath, 2014, 2017). This new approach studies man as a whole through his subjectivity, personal characteristics, and the strengths that specify him and the environment in which he evolves. By consulting the site dedicated to the study of character strengths (www.viacharacter.org), we noticed that different fields of psychology have been the subject of strength experimentation. A section of the website is dedicated to each of the domains. We were challenged by the absence of a section dedicated to counselling psychology. Does this mean that it has not yet attracted the attention of researchers in positive psychology? Would not it be 
useful to use character strengths at different times of life requiring professional counselling? Or perhaps has there been no interest in studying career guidance outside the institutional context? Yet, counselling psychology increasingly covers individuals who seek to improve their well-being, to make sense of their lives while developing and building themselves throughout life. Far from the linear conception of counselling of the Parsons era (1909), where career paths used to be defined in advance, current career paths are fragmented and scattered, thus weakening the well-being of individuals. Focusing on one's own character strengths is a great opportunity to value one's self and optimize his functioning. The importance of applying character strengths in the field of professional counselling is presented in the next section.

\section{Positive Psychology and Character Strengths}

Representing a cross-cutting approach that can serve the theories and interventions rather than a sub-discipline of psychology (Bernaud et al., 2015), positive psychology is the scientific study of human strengths and virtues that aim to develop what characterizes us best. It is a science devoted to the study of the vitality and virtues of ordinary people. Thus, it helps individuals, communities, and societies to develop and promote the qualities that lead to their own self-fulfillment and that of others (Seligman \& Csikszentmihalyi, 2000). The definition that best describes the purpose of his study is that of Shelly Gable and Jonathan Haidt (2005: p. 104) for whom "positive psychology is the study of the conditions and processes that contribute to the flourishing or optimal functioning of people, groups, and institutions".

The term "positive psychology" first appeared in 1954 in the final chapter of Abraham Maslow's book Personality \& Motivation. The term is used to describe the characters a person needs to function in an optimal way. Long forgotten, the term "positive psychology" resurfaced in 1998 with Martin Seligman (professor at the University of Pennsylvania) at the time he was elected president of the APA (American Association of Psychology). Seligman positions positive psychology as a discipline in its own right whose field of study is the scientific study of optimal human functioning. The year 2000 witnessed the founding act of positive psychology through the publication in the American journal, "American Psychologist", (Seligman \& Csikszentmihalyi, 2000) of a special issue devoted to the current of positive psychology.

The main idea of the new approach is that one way of solving problems is to identify and exploit the strengths and assets of the individual (Park \& Peterson, 2008; Park, Peterson, \& Brunwasser, 2009). The researchers found that some existing human strengths, to varying degrees, in all individuals prevented mental illness: courage, hope, faith, future orientation, perseverance, etc. (Peterson \& Seligman, 2004). These theories see individuals as decision-making beings who have choices, preferences, and the opportunity to learn and grow throughout life (Martin-Krumm, Tarquinio, \& Delle Fave, 2011). For this purpose, Peterson and 
Seligman (2004) have established a classification of personality traits that are morally valued in different cultures of the world. The authors attributed the name: Values In Action (VIA) to this classification. They hoped to conceive for positive psychology a tool based on moral excellence (character strengths and virtues). The objective of positive psychology is, therefore, to promote the strengths of everyone in order to reach an optimal functioning that would be the origin of happiness.

\section{Character Strengths and the Values in Action (VIA) Model}

Character strengths have been defined as "the processes or mechanisms of psychological substrates that define virtues" (Peterson \& Seligman, 2004: p. 13).

It is a classification of the good traits of the individual's personality. This definition is largely influenced by the moral personality and the virtues that constitute it. One of the definitions of virtue was given by Yearley (1990: p. 38): "a disposition to act, desire, and feel that involves the exercise of judgment and leads to a recognizable human excellence or instance of human flourishing." Drawing on both the psychology of personality and moral values, the model is meant to bring together contemporary psychology with traditional moral philosophy. For this end, Peterson and Seligman (2004) initiated a research program based on the description of the most salient strengths of the individual and their evaluation as individual differences. This is about the Values In Action project (VIA) that presents itself under 24 strengths grouped in six virtues. The use of the term VIA is a terminology used to account for a psychological conception of the personal qualities of an individual that makes him morally admirable. The theoretical context from which the VIA project emerged is characterized by three elements: the spirit of positive psychology, the roots of trait theory and, in particular, religious philosophical traditions.

1) The classification of character strengths accentuates the effort of positive psychology to thwart traditional psychology, with its alleged negligence of positive human functioning. The VIA classification was specifically proposed in response to the most prevalent psychiatric classification of mental disorders, namely DSM (APA, 2000), and its predominance in psychology. Peterson and Seligman (2004: p. 8) hoped to "conceive, for positive psychology, a tool based on moral excellence (character strengths and virtues)".

2) The second pillar is the psychology of personality or, more specifically, the theory of traits (Allport, 1961). The working hypothesis that the authors have adopted considers the character as "plural". Character, therefore, is understood as "a family of largely valued traits, each of which exists to varying degrees and manifests itself in a category of thoughts, feelings, and behaviors" (Park et al., 2009: p. 137).

3) The last theoretical element is the ethics of virtue. Peterson and Seligman (2004: pp. 9-10) explicitly state that their classification is "grounded in a long philosophical tradition concerned with morality explained in terms of virtues".

In addition to the theoretical backgrounds presented above, the model is also 
based on strictly quantitative empirical fundamentals, which are at the basis of classification. In developing the VIA, the authors conducted a thorough cross-cultural analysis through a study centered on "the most influential traditions of thought in human history". These studies have explored traditions in countries such as China, South Asia (mainly India) and the West (p. 34), although they have chosen Confucianism and Taoism more specifically for China, Buddhism and Hinduism for South Asia as well as Judeo-Christianity for Ancient Greece and Islam for the East (Dahlsgaard, Peterson, \& Seligman, 2005). The results of the study led the authors to conclude that there were "great similarities between cultures (p. 36). In particular, they claimed to have found "a historical and intercultural convergence" (p. 50) of six fundamental virtues: wisdom, courage, justice, humanity, temperance, transcendence. Due to the surprising ubiquity of these character traits, the authors decided to consider them as omnipresent in all major religious and cultural traditions" (Seligman, 2002: p. 130). The outcomes of these different researches have resulted in a complete typology categorized into six virtues-wisdom, courage, humanity, justice, temperance, and transcendence-which have been identified as core characteristics by moral philosophers, religious thinkers across the history and cultures of the world (Peterson \& Seligman, 2004). Twenty-four corresponding character strengths- "psychological components" or pathways to these virtues-come from a long list of subjects that have been carefully researched (Peterson \& Seligman, 2004) (see Table 1).

The VIA model is a discovery in "the psychology of positive personality". It is a model that incorporates personality traits, moral values and skills. This classification allows us, therefore, to describe and study the "good morality" that paves the way to pleasure, commitment and, more generally, positive experiences (Peterson et al., 2007; Seligman, 2011). The work on the VIA model expands thinking about what is meant by the word character, which has different meanings within and across cultures. Traditional conceptions of character usually identify a few traits and claim that each person should strive to develop as much of this set of basic characteristics as possible (Niemiec, 2013). If character strengths are then conceived as virtuous personality traits, it is because they

Table 1. VIA classification (Peterson \& Seligman, 2004).

\begin{tabular}{|c|c|c|}
\hline Virtues & Type of strength & Corresponding strengths \\
\hline Wisdom & Cognitive strengths & $\begin{array}{c}\text { Creativity - Curiosity - Judgment - Love of Learning - } \\
\text { Perspective }\end{array}$ \\
\hline Courage & Emotional strengths & Bravery - Honesty - Perseverance - Zest \\
\hline Humanity & $\begin{array}{l}\text { Interpersonal } \\
\text { strengths }\end{array}$ & Kindness - Love - Social Intelligence \\
\hline Justice & Civic strengths & Fairness - Leadership - Teamwork \\
\hline Temperance & Regulation strength & Forgiveness - Humility - Prudence - Self regulation \\
\hline Transcendence & Spiritual & $\begin{array}{l}\text { Appreciation of beauty - Gratitude - Hope - Humor - } \\
\text { Spirituality }\end{array}$ \\
\hline
\end{tabular}


consequently provide a sense of well-being and give meaning to our actions, particularly in societies characterized by instability. This model did not remain only conceptual but was also meant to be practical. The authors have thus constructed a tool to measure these character strengths.

\section{The VIA-IS: A Flagship Tool for Strength Measurement}

Even though two tools to measure character strengths currently exist: Realise2 (Linley, 2009) and Clifton Strengths-Finde (CSF) (Asplund, Lopez, Hodges, \& Harter, 2007), the Values In Action Inventory of Strengths (VIA-IS, Peterson \& Seligman, 2004) is the most used tool. The inventory, which was elaborated as an antithesis to the DSM, is based on the belief that strengths are the real manifestation of virtues and are associated with well-being. After several trials, researchers (Park \& Peterson, 2006, Peterson, Park, \& Seligman, 2005), elaborated a list of 24 forces organized into six virtues (wisdom and knowledge, courage, humanities, justice, temperance and transcendence). This inventory is designed to describe individual differences in character strengths as a continuum rather than a discontinuity. Initially, it gathers 240 items (10 for each force) on a 5-point Likert scale for a duration of 30 minutes. The scales showed a fairly satisfactory internal consistency (McGrath, 2014) and a test-retest validity after a period of 4 months. In terms of validity, the correlations are higher than expected.

The VIA-IS Character Strength Inventory has been used by more than one million people and is a free online tool. The VIA-IS has been translated into 39 languages and is currently being translated into 20 other languages, including Urdu, Farsi and Portuguese (McGrath, 2017). The richness of these translations supports the need to explore character strengths and the ambition to generalize the model to all cultures and domains. The VIA classification and the VIA-IS Inventory of Character Strengths are widely used by researchers and practitioners around the world (Niemiec, 2013). This work on character strengths is one of the most important initiatives since the birth of positive psychology. The VIA classification research (Peterson \& Seligman, 2004) is flourishing and practitioners, ranging from psychologists and coaches to business leaders and educators, are eager to find ways to apply research to their practices. That said, applied research on the 24-character strengths-their use in practice, the effect of strength combinations, and the results of each-is a relatively new terrain. To what extent can character strength then be applied to professional counseling?

\section{Character Strengths and Counseling Psychology}

The first value that currently underpins counseling psychology research is concerned with the people's assets, their resources, strengths, mental health apart from their psychological disorders (Gelso et al., 2014a). We would like to point out that character strengths as a subject of study of positive psychology have long been studied and applied in the field of health care. Their application in the field of counseling began to emerge only a few years ago with the research done 
by Littman-Ovadia, Lazar-Butbul, \& Benjamin (2014) and Owens, Motl, \& Krieshok (2016). Nevertheless, if we look back into the history of psychology, we find a particular interest in character strengths in the field of professional counseling since the beginning of the twentieth century.

Indeed, the concept associated with character strengths, namely "optimal functioning" has been, from the beginning, an integral part of the psychology of counseling and guidance (Hartung, Savickas, \& Walsh, 2015). This orientation began with the approach of Donald Super (1955) who perceived the counseling in the space of a life more from an angle of health than disease. Thus, counseling and guidance psychologists have begun to work on the strengths and potentials of individuals in order to develop them. This view of research is typical of the hope and optimism that underpins this approach:

"Individuals can change, have a life satisfaction, orient themselves and find ways to use their resources, otherwise they will be caught up in and overwhelmed by limiting beliefs and feelings, a slowed down maturation, bad luck in opportunities, and diseases" (Jordaan, Myers, Layton, \& Morgan, 1968: p. 2).

The focus on strengths is more noticeable in its developmental role of helping individuals "feel better rather than feel good" Menninger, Mayman, \& Pruyser (1963). Adherence to this state of mind has been noted over the past 15 - 20 years prior to the 1950s, as evidenced by the work of the Joint Commission on Mental Illness and Mental Health (1961). For this purpose, the reflections of Jahoda (1958) within this commission have attracted attention:

"We commonly use 'mental health' as an interchangeable term with 'mental illness' in the same euphemistically insinuating direction that public health generally refers to the prevention and monitoring of the disease by massive methods. Behavioral scientists who joined the mental health team and made a major contribution to the mental health movement expressed dissatisfaction with the primary goal of studying 'pathological behavior'. They proposed new, broader perspectives to consider mental health as a positive force and make it a clear and useful concept in practice."

During this period, important contributions and concepts related to the high level of optimal functioning were developed: Rogers (1961) with the optimal functioning of the person, Allport (1963) with mature personality, Heath (1999) with the reasonable adventurer, Maslow (1970) with self-actualization. However, these models have not been developed in the context of counseling psychology or guidance even though some have tried to incorporate them into their work.

Strengths represent the almost perfect performance of a task by combining talents, knowledge and skills. The optimal use of human strengths has been the goal of counseling psychology since the work of Frank Parsons, founder of the discipline. Parsons' goal was to help people make a "wise" choice of their vocation. He strove to do this by implementing a three-step process, which included self-exploration, exploring the world of work, and selecting opportunities that fit both perfectly (Robitschek \& Woodson, 2006). Following Parsons' initiative, counseling psychology has long emphasized individual strengths (Robitschek \& 
Woodson, 2006). This positive focus can easily be seen through the positive language used in current research, "improving job satisfaction", "well-being at work", and "hope at work".

Although no theory in counseling psychology explicitly claims to borrow elements from positive psychology, the themes that unite them are very similar and often share a focus on self-esteem and self-efficacy (Robitschek \& Woodson, 2006). Savickas (2005) has described a taxonomy of attitudes, beliefs, and coping skills that subsumes the virtues identified by Seligman (1998), including courage, optimism, interpersonal skills, hope, perseverance, and ethics at work. Savickas (2011) has argued that career education and counseling can help strengthen the character strengths of customers. Thus, identifying and promoting assets offers a unique perspective to career seekers or those who have already started it. Before the career exploration process (for example, asking questions, gathering information and interacting with various work environments; Super, 1980), it would probably be useful to identify strengths to determine how to apply them to professional opportunities. For Linley \& Harrington (2006: p. 318), individuals can "build on their strengths" or adapt effectively to different environments using their character strengths. The extent to which a person can adapt to their roles and work environment is an essential part of maintaining life satisfaction.

Savickas (2003) argued that psychology should resume work on its initial subject of study, which is based on the "construction of human strength", including in the field of counseling psychology. Positive contributions to counseling psychology, based on character strengths, would then enable individuals to deepen self-knowledge in order to make much more serene orientation choices. Following these, some contributions based on character strengths began to budge.

\section{Development of Positive Interventions in Counseling Psychology}

Counseling psychologists have paid considerable attention to the way in which consultants use and manage their strengths. Yet, until nowadays, there is little written literature and concrete empirical research that explains how advisors do to work on the strengths of consultants. It is only since the last ten years that research has focused its studies on the understanding and implementation of a support mechanism for the promotion of strengths, even if the arrangements in positive psychology centered on careers are almost exclusively based on therapies (Gelso et al., 2014b). These different interventions are presented in Table 2 .

- The first approach, SCT, is a psychotherapeutic approach designed to enhance character strengths and virtues as defined by (Peterson \& Seligman, 2004). It helps to facilitate changes. The approach consists of four steps (1. explicitizing, 2. envisioning, 3. empowering, 4. evolving).

- The second intervention (SBC) allows to develop strengths to help people better solve the problems of their lives. It orients the psychologist to know 
Table 2. Positive interventions based on strengths

\begin{tabular}{|c|c|c|c|}
\hline Approach & Population & Authors + date & Measures \\
\hline 1) Strengths Centered Therapy (SCT) & Adults & Wong, 2006 & VIA-IS \\
\hline 2) Strengths-Based Counseling (SBC) & Adolescents & Smith, 2006 & None \\
\hline 3) Strengths Mentoring (SM) & Students & $\begin{array}{l}\text { Lopez et al., } \\
2006\end{array}$ & $\begin{array}{c}\text { Clifton Strengths } \\
\text { Finder (CSF) }\end{array}$ \\
\hline 4) Positive Psychology Interventions (PPI) & Adults & $\begin{array}{l}\text { Seligman } \\
\text { et al., } 2005\end{array}$ & VIA-IS \\
\hline 5) Strength-Based Career Counseling (SBCC) & $\begin{array}{c}\text { Unemployed } \\
\text { job-seeking }\end{array}$ & 2014 & VIA-IS \\
\hline
\end{tabular}

and look for what distinguishes each adolescent from the others in terms of assets, know-how and how they succeed in doing so while others fail. This process takes place in 10 steps:

a) Establish a therapeutic relationship for the importance of protocol + commitment,

b) Identify strengths via a narrative method, in order to help individuals know their strengths and internalize them,

c) Evaluate the problem presented in order to clarify the client's interest,

d) Encourage hope,

e) Framing solutions relies heavily on solution-focused strategies,

f) Build strengths and foster skills,

g) From 7 to 9: empowering, changing and building resilience in order to promote agency and facilitate goal pursuit,

h) Evaluate

- The third intervention (SM) was designed to develop student strategies and promote academic effectiveness feeling, hope (Snyder, 1994) and self-help growth. This is a three-session process to promote the intentional use of strengths.

- The fourth approach aims to promote strengths for the pursuit of happiness: 5 exercises, 3 of which aim at identifying and understanding character strengths. Knowledge of one's strengths allows individuals to consider opportunities for using them to promote well-being. The $4^{\text {th }}$ exercise is based on documenting the "blessings in life" (ask the subject to write 3 things they do well every day for a week and write down the reasons for doing it well. The fifth exercise is based on the moment when these people do things well and when they are at their best.

- The SBCC developed by Littman-Ovadia, Lazar-Butbul, \& Benjamin (2014), mobilizes four sessions.

a) The first session includes a brief intake interview, gathering information on the clients' past work experiences, education and training. The counselor then helps clients articulate their employment-related counseling goals in clear, positive, and realistic terms. 
b) During the second session, the clients are encouraged to recognize their strengths, according to the VIA classification. After defining their goals, the counseling process moves to the stage of linking strengths to achieving personal and professional goals. The counselor and client discuss the contribution of strengths to the client's life, while focusing on employment and how the client could use these strengths to advance and achieve the previously stated goals.

c) The third session begins with a review of the tasks assigned in the previous session and a discussion of the clients' progress. They identify the strengths that customers would like to develop for the future while reinforcing what has already been accomplished.

d) In this closing session, the counselor and the client revisit the achievements made in the area of strength development. The counselor and the client identify significant changes that occurred during the strength development process. The advisor determines with clients how to use the personal resources available to face future challenges.

These different strength-based interventions have been conducted with different audiences and have proved their effectiveness (Owens, Motl, \& Krieshok, 2016). However, the interest for character strengths in the field of vocational counseling remains nascent but offers interesting prospects in relation to the positive effects they may have on the functioning. We hope to see many interventions in the field of counseling in the field of positive psychology (Bernaud, 2013, 2016).

\section{Conclusion}

The finding has been established that positive psychology is moving towards a future where it will be more and more present in the different spheres of life, affecting many aspects of the individual that are related to his functioning (Martin-Krumm, 2017; Peterson, 2006; Seligman \& Csikszentmihalyi, 2000). It has also been introduced a few years ago in the field of counseling psychology through four stages: the grouping of universal theories on human functioning, finding methods based on strengths that do not necessarily belong to the medical domain; working on the positive traits of people and positive experiences and emotions that allow them to be happy. Similarly, it is gradually finding a niche in the training of the guidance counselor (Sovet et al., 2018). The applications of these positivist approaches have, in fact, very quickly been echoed in the field of counseling psychology (Hirschi, 2011, Richardson, Constantine, \& Washburn, 2005, Rottinghaus et al., 2005).

Character strengths as psychological resources can then be a cornerstone in the new paradigm of counseling. Identifying and promoting forces offers a new perspective for consultants and counselors to explore the field of counseling. The identification of strengths would probably be beneficial in determining how they can be applied to the opportunities offered to the individual in periods of professional transitions (Kidd \& Davidson, 2007). Thus, it becomes indisputable that character strengths constitute, as psychological resources, a real engine for indi- 
viduals to build their lives by themselves and adapt to their context and environment, as long as these forces are virtuous and fulfilling.

\section{Conflicts of Interest}

The author declares no conflicts of interest regarding the publication of this paper.

\section{References}

Allport, G. W. (1961). Pattern and Growth in Personality. New York: Holt, Rinehart \& Winston.

Allport, G. W. (1963). Behavioral Science, Religion, and Mental Health. Journal of Religion and Health, 2, 187-197.

American Psychiatric Association (2000). Diagnostic and Statistical Manual of Mental Disorders (4th ed., Text Revision). Washington DC: Author.

Asplund, J., Lopez, S. J., Hodges, T., \& Harter, J. (2007). The Clifton Strengths Finder 2.0 Technical Report: Development and Validation. Princeton, NJ: Gallup Press.

Bernaud, J.-L. (2013). Adaptive Counseling Theory: A New Perspective for Career Counseling. In K. Maree, \& A. Di Fabio (Eds.), Psychology of Counseling. New-York: Nova Science Publishers.

Bernaud, J.-L. (2016). Le sens de la vie comme paradigme pour le conseil en orientation. Psychologie Française, 61, 61-72. https://doi.org/10.1016/j.psfr.2013.06.004

Bernaud, J.-L., Lhotellier, L., Sovet, L., Arnoux-Nicolas, C., \& Pelayo, F. (2015). Psychologie de l'accompagnement. Concepts et outils pour construire le sens de la vie et du travail. Paris: Dunod. https://doi.org/10.3917/dunod.berna.2015.01

Dahlsgaard, K., Peterson, C., \& Seligman, M. E. (2005). Shared Virtue: The Convergence of Valued Human Strengths across Culture and History. Review of General Psychology, 9, 203-213. https://doi.org/10.1037/1089-2680.9.3.203

Gable, S. L., \& Haidt, J. (2005). What (and Why) Is Positive Psychology? Review of General Psychology, 9, 103-110. https://doi.org/10.1037/1089-2680.9.2.103

Gelso, C. J., Nutt Williams, E., \& Fretz, B. R. (2014a). An Introduction to Counseling Psychology. In C. J. Gelso, E. Nutt Williams, \& B. R. Fretz (Eds.), Counseling Psychology(3rd ed., pp. 3-23). Washington DC: American Psychological Association. https://doi.org/10.1037/14378-001

Gelso, C. J., Nutt Williams, E., \& Fretz, B. R. (2014b). Working with Strengths: Counseling Psychology's Calling. In C. J. Gelso, E. Nutt Williams, \& B. R. Fretz (Eds.), Counseling Psychology (3rd ed., pp. 157-178). Washington DC: American Psychological Association. https://doi.org/10.1037/14378-007

Hartung, P. J., Savickas, M. L., \& Walsh, W. B. (2015). APA Handbook of Career Intervention. Vol. 1. Foundations. Washington DC: American Psychological Association. https://doi.org/10.1037/14438-000

Heath, C. (1999). On the Social Psychology of Agency Relationships: Lay Theories of Motivation Overemphasize Extrinsic Incentives. Organizational Behavior and Human Decision Processes, 78, 25-62. https://doi.org/10.1006/obhd.1999.2826

Hirschi, A. (2011). Effects of Orientations to Happiness on Vocational Identity Achievement. The Career Development Quarterly, 59, 367-378.

https://doi.org/10.1002/j.2161-0045.2011.tb00075.x

Jahoda, M. (1958). Current Concepts of Positive Mental Health. New York: Basic Books. 
https://doi.org/10.1037/11258-000

Jordaan, J. P., Myers, R. A., Layton, W. C., \& Morgan, H. H. (1968). The Counseling Psychologist. Washington DC: American Psychological Association.

Kidd, S. A., \& Davidson, L. (2007). You Have to Adapt Because You Have No Other Choice: The Stories of Strength and Resilience of Homeless Youth in New York and Toronto. Journal of Community Psychology, 35, 219-238. https://doi.org/10.1002/jcop.20144

Linley, P. A. (2009). Technical Manual and Statistical Properties of Realise 2. Coventry: Centre of Applied Positive Psychology.

Linley, P. A., \& Harrington, S. (2006). Playing to Your Strengths. Psychologist, 19, 86-89.

Littman-Ovadia, H., Lazar-Butbul, V., \& Benjamin, B. A. (2014). Strengths-Based Career Counseling: Overview and Initial Evaluation. Journal of Career Assessment, 22, 403-419. https://doi.org/10.1177/1069072713498483

Lopez, S. J., Tree, H., Bowers, K., \& Burns, M. E. (2006). Positive Psychology on Campus: Discovering Students' Strengths. In S. J. Lopez's (Chair) Symposium: Positive Psychology on Campus. Presented at the 5th Gallup International Positive Psychology Summit, Washington DC.

Martin-Krumm, C. (2017). Psychologie positive, quelle part d'innovation? Le Journal des Psychologues, 346, 14. https://doi.org/10.3917/jdp.346.0014

Martin-Krumm, C., Tarquinio, C., \& Delle Fave, A. (2011). Traité de psychologie positive. Bruxelles: De Boeck.

Maslow, A. H. (1970). Motivation and Personality. New York: Harper \& Row.

McGrath, R. E. (2014). Scale- and Item-Level Factor Analyses of the VIA Inventory of Strengths. Assessment, 21, 4-14. https://doi.org/10.1177/1073191112450612

McGrath, R. E. (2017). The VIA Assessment Suite for Adults (p. 63). Cincinnati, OH: VIA Institute on Character.

Menninger, K., Mayman, M., \& Pruyser, P. (1963). The Vital Balance: The Life Process in Mental Health and Illness. New York: Penguin Books.

Niemiec, R. M. (2013). VIA Character Strengths: Research and Practice (The First 10 Years). In H. H. Knoop, \& A. Delle Fave (Éds.), Well-Being and Cultures (Vol. 3, pp. 11-29). Dordrecht: Springer Netherlands. https://doi.org/10.1007/978-94-007-4611-4_2

Owens, R. L., Motl, T. C., \& Krieshok, T. S. (2016). A Comparison of Strengths and Interests Protocols in Career Assessment and Counseling. Journal of Career Assessment, 24, 605-622. https://doi.org/10.1177/1069072715615854

Park, N., \& Peterson, C. (2006). Moral Competence and Character Strengths among Adolescents: The Development and Validation of the Values in Action Inventory of Strengths for Youth. Journal of Adolescence, 29, 891-909. https://doi.org/10.1016/j.adolescence.2006.04.011

Park, N., \& Peterson, C. (2008). Positive Psychology and Character Strengths: Application to Strengths-Based School Counseling. Professional School Counseling, 12, 85-92. https://doi.org/10.5330/PSC.n.2010-12.85

Park, N., Peterson, C., \& Brunwasser, S. M. (2009). Positive Psychology and Therapy. In N. Kazantzis, M. A. Reinecke, \& A. Freeman (Eds.), Cognitive and Behavioral Theories in Clinical Practice (pp. 278-306). New York: Guilford.

Parsons, F. (1909). Choosing a Vocation. Boston, MA: Houghton Mifflin.

Peterson, C. (2006). A Primer in Positive Psychology. New York: Oxford University Press.

Peterson, C., \& Seligman, M. E. P. (2004). Character Strengths and Virtues: A Handbook 
and Classification. New York: Oxford University Press.

Peterson, C., Park, N., \& Seligman, M. E. P. (2005). Orientations to Happiness and Life Satisfaction: The Full Life versus the Empty Life. Journal of Happiness Studies, 6, 25-41. https://doi.org/10.1007/s10902-004-1278-Z

Peterson, C., Ruch, W., Beermann, U., Park, N., \& Seligman, M. P. (2007). Strengths of Character, Orientations to Happiness, and Life Satisfaction. The Journal of Positive Psychology, 2, 149-156. https://doi.org/10.1080/17439760701228938

Richardson, M. S., Constantine, K., \& Washburn, M. (2005). New Directions for Theory Development in Vocational Psychology. In W. B. Walsh, \& M. L. Savickas (Eds.), Handbook of Vocational Psychology (3rd ed., pp. 51-84). Mahwah, NJ: Lawrence Erlbaum Associates.

Robitschek, C., \& Woodson, S. J. (2006). Vocational Psychology: Using One of Counseling Psychology's Strengths to Foster Human Strength. The Counseling Psychologist, 34, 260-275. https://doi.org/10.1177/0011000005281321

Rogers, C. R. (1961). On Becoming a Person. Boston: Houghton Mifflin.

Rottinghaus, P. J., Day, S. X., \& Borgen, F. H. (2005). The Career Futures Inventory: A Measure of Career-Related Adaptability and Optimism. Journal of Career Assessment, 13, 3-24. https://doi.org/10.1177/1069072704270271

Savickas, M. (2011). Career Counseling. Washington DC: American Psychological Association.

Savickas, M. L. (2003). Toward a Taxonomy of Human Strengths: Career Counseling's Contribution to Positive Psychology. In W. B. Walsh (Ed.), Counseling Psychology and Optimal Human Functioning (pp. 229-249). Mahwah, NJ: Lawrence Erlbaum.

Savickas, M. L. (2005). The Theory and Practice of Career Construction. In S. D. Brown, \& R. W. Lent (Eds.), Career Development and Counselling: Putting Theory and Research to Work (pp. 42-70). Hoboken, NJ: Wiley.

Seligman, M. E. (1998). The President's Address. American Psychologist, 54, 559-562.

Seligman, M. E. P. (2002). Authentic Happiness. New York: Free Press.

Seligman, M. E. P. (2011). Flourish. New York: Free Press.

Seligman, M. E. P., \& Csikszentmihalyi, M. (2000). Positive Psychology: An Introduction. American Psychologist, 55, 5-14. https://doi.org/10.1037/0003-066X.55.1.5

Seligman, M. E. P., Steen, T. A., Park, N., \& Peterson, C. (2005). Positive Psychology Progress. American Psychologist, 60, 410-421. https://doi.org/10.1037/0003-066x.60.5.410

Smith, E. J. (2006). The Strength-Based Counseling Model. The Counseling Psychologist, 34, 13-79.

Snyder, C. R. (1994). The Psychology of Hope: You Can Get There from Here. New York: Free Press.

Sovet, L., Annovazzi, C., Ginevra, M. C., Kaliris, A., \& Lodi, E. (2018). Life Design in Adolescence: The Role of Positive Psychological Resources. In V. Cohen-Scali, J. Rossier, \& L. Nota (Eds.), New Perspectives on Career Counseling and Guidance in Europe (pp. 23-37). https://doi.org/10.1007/978-3-319-61476-2_2

Super, D. E. (1955). Transition: From Vocational Guidance to Counseling Psychology. Journal of Counseling Psychology, 2, 3-9. https://doi.org/10.1037/h0041630

Super, D. E. (1980). A Life-Span, Life-Space Approach to Career Development. Journal of Vocational Behavior, 16, 282-298. https://doi.org/10.1016/0001-8791(80)90056-1

Wong, Y. J. (2006). Strengths-Centered Therapy: A Social Constructionist, Virtues-Based 
Psychotherapy. Psychotherapy: Theory, Research, Practice, and Training, 43, 133-146. https://doi.org/10.1037/0033-3204.43.2.133

Yearley, L. H. (1990). Mencius and Aquinas: Theories of Virtue and Conceptions of Courage. Albany: State University of New York Press. 